A

\title{
Regerach article: Constraints faced by the respondents and their suggestions in adopting pigeonpea production technology
}

\author{
R.D. AHIRE, R.S. KARHALE AND R.P. KADAM
}

Article Chronicle :

SUMMARY : The present study was conducted with specific objectives to study technological gap in pigeonpea production technology. For this study Parbhani district was selected and from Parbhani Received : 20.09.2015;

Revised :

07.10.2015;

Accepted :

21.10.2015 district three talukas viz., Gangakhed, Jintur and Parbhani were selected. From these three talukas twelve village were selected randomly and ten respondents from each village were selected, i.e. 120 respondents from 12 villages constituted the sample for the study. Ex-Post Facto research design was used for the research study. The major constraints faced by respondents in technological gap in pigeonpea production technologies were high cost of FYM, high cost of chemical fertilizer, lack of knowledge about benefits of intercultural operation, non- availability of bio-fertilizer and fungicide for seed treatment in rural area. The majority of the respondents suggested that cost of seed should be reduced, training programme should be organized to improve the knowledge regarding land use, bio-

KEY WoRds:

Technological gap, Constraints, Suggestions, Pigeonpea, Production technology

Author for correspondence :

\section{R.P. KADAM}

Department of Extension Education, College of Agriculture, Vasantrao Naik Marathwada Krishi Vidyapeeth, PARBHANI (M.S.) INDIA

Email:rpk.mkv@gmail. com

See end of the article for authors' affiliations fertilizer and detail package of practices, mechanical threshers should be made available to groups by providing 100 per cent subsidy.

How to cite this article : Ahire, R.D., Karhale, R.S. and Kadam, R.P. (2015). Constraints faced by the respondents and their suggestions in adopting pigeonpea production technology. Agric. Update, 10(4): 335-339. 